\title{
Diallel analysis of seven promising genotypes of opium poppy for assessment of their combining ability and efficacy in future genetic improvement programmes
}

\author{
Rashmi Lahiri" ${ }^{*}$, Jyotshana², A.K. Verma ${ }^{3}$, Karuna Shanker², R.K. Lal' \\ ${ }^{1}$ Department of Genetics and Plant Breeding, CSIR-Central Institute of Medicinal and Aromatic \\ Plants, Lucknow 226015, India \\ ${ }^{2}$ Department of Analytical Chemistry, CSIR - Central Institute of Medicinal and Aromatic Plants, \\ Lucknow 226015, India \\ ${ }^{3}$ Botanical Survey of India, Central Regional Center, Allahabad 211002, India
}

*Corresponding author, E-mail: rashmilahirigzb@gmail.com

\begin{abstract}
Opium poppy (Papaver somniferum L.) is a widely cultivated plant species, producing a number of pharmaceutically important alkaloids and highly nutritive seeds. In the present investigation, combining ability analysis and reciprocal effect were studied in a $7 \times 7$ diallel set of opium poppy. Analysis of variance revealed the presence of significant variance due to general combining ability (GCA), specific combining ability (SCA) and reciprocal effect among the parents for all the traits except for codeine content. Combining ability analysis revealed the involvement of both additive and non-additive gene action in the inheritance of most of the traits. On the basis of GCA, SCA effects and per se performance, genotype SPS-20, Sanchita and Ajay were identified as the most eligible parents for future hybridization programmes for better seed yield, development of morphine-less cultivars and quantitative improvement of different types of alkaloid in poppy straw, respectively.
\end{abstract}

Key words: combining ability, diallel analysis, genetic improvement, opium poppy, Papaver sominferum, reciprocal effect. Abbreviations: GCA, general combining ability; SCA, specific combining ability; gi, estimate of GCA effect; Sij, estimate of SCA effect; Srj, estimate of reciprocal effect.

\section{Introduction}

Opium poppy (Papaver somniferum L., Papaveraceae) is a medicinal plant cultivated globally for the production of pharmaceutically important opiates and heroin (Marciano et al. 2018). P. somniferum is considered as the only source for several high-value pharmaceutically important benzylisoquinoline alkaloids including narcotic analgesics morphine and thebain, antitussive agent codeine, anticancer drug noscapine, antimicrobial agent sanguinarine and vasodilator agent papaverine (Pathak et al. 2013), which are utilized as a major feedstock for synthesis of important drugs (Frick et al. 2005). Moreover, the species is also acknowledged for nutraceutical value of its seeds as a rich source of essential minerals, protein $(24 \%)$, and linoleic acid (68\%), which help to lower blood cholesterol levels (Vos, Cunnne 2003; Sacks, Compos 2006). Owing the economical value, there is a significant interest for genetic improvement of $P$. somniferum. Among the unexplored aspects, evaluation of different germplasm for their agronomic traits, yield component and combining ability are most imperative ones as offering precious information necessary for development of elite genotypes with desirable traits. In this context, traditional diallel analysis is more efficient and frequently utilized to acquire information on genetic effects, an approximate estimate of general combining ability (GCA) and specific combining ability (SCA), heritability for a population of parental lines, and to identify the potential heterotic combinations as well as heterotic patterns (Bertoria et al. 2006; Rastogi et al., 2013).

Several recent studies attempted diallel crosses in diverse genotypes of $P$. somniferum to understand inheritance of various agronomic traits and their combining ability (Lal et al. 2014; Shukla et al. 2019; Yazici, Yilmaz 2020), but still there are unresolved issues in this respect. To obtain further information necessary for identification of suitable genetic stocks for future hybridization programmes, more concerted efforts are needed. In the present investigation, seven genotypes of opium poppy were crossed in diallel fashion and screened for performance of their $\mathrm{F}_{1}$ progeny, their breeding potential in specific combination, and for the whole performance of the hybrids, in order to select 
the promising genotypes for future yield improvement programmes.

\section{Materials and methods}

In the present study, seven genotypes of $P$. somniferum (Shweta, Sujata, SPS-20, Sanchita, Ab-1, CIMAP-Ajay, and Dr-44) belonging to different genetic stocks, improved varieties and land races were collected or procured from different eco-geographical regions of the world. In the milieu of qualitative and quantitative yield, the performance of all accessions was evaluated by growing them at the experimental field of Genetics \& Plant Breeding Unit of CSIR, CIMAP, Lucknow, located at $26.5^{\circ} \mathrm{N}$ and $80.50^{\circ} \mathrm{E}$, $120 \mathrm{~m}$ above sea level, in November to April during 2013 - 2014 and 2014 - 2015. Later, a pure line progeny was selected as a parent and used for diallel analysis $\left(\mathrm{P}_{1}-\mathrm{P}_{7}\right.$, Table 1).

All parents were crossed in a diallel mating design in all possible combinations, including reciprocals to obtain $\mathrm{F}_{1}$ seeds (Griffing 1956a; Griffing 1956b). The hybridization and evaluation of $F_{1}$ hybrids were performed in 2015 2016 and 2016 - 2017, respectively. All hybrids, including parents, $F_{1}$ and reciprocals, were grown in a randomized block design with three replications from November to April. One row of each entry was grown in each replication with spacing of $10 \mathrm{~cm}$ between plants within rows and $40 \mathrm{~cm}$ between rows. Standard cultural practices were followed throughout the cropping season, which included pre-sowing addition of farmyard manure at a rate of 10 t ha ${ }^{-1}$ nitrogen, $80 \mathrm{~kg} \mathrm{ha}^{-1}$ phosphorus, and $40 \mathrm{~kg} \mathrm{ha}^{-1}$ potassium. The data for 13 agronomic traits (days to $50 \%$ flowering, plant height, peduncle length, days to maturity, number of capsules per plant, capsule index, seed yield per plant, capsule husk yield per plant, straw alkaloid content i.e. morphine, codeine, thebaine, papaverine and narcotine)
Table 1. Parent Papaver somniferum genotypes used in diallel analysis

\begin{tabular}{|llll} 
No. & Abbreviation & Name & Source of origin \\
1 & P1 & Shweta & CIMAP, Lucknow, India \\
\hline 2 & P2 & Sujata & CIMAP, Lucknow, India \\
\hline 3 & P3 & SPS- 20 & CIMAP, Lucknow, India \\
\hline 4 & P4 & Sanchita & CIMAP, Lucknow, India \\
\hline 5 & P5 & Ab-1 & Kosice, Slovak Republic \\
\hline 6 & P6 & Ajay & CIMAP, Lucknow, India \\
\hline 7 & P7 & Dr 44 & CIMAP, Lucknow, India \\
\hline
\end{tabular}

were recorded as per the adopted methodology (Yadav et al. 2009a; b)

For chemical analysis, the dried powder of capsule husk ( $1 \mathrm{~g})$ was first dissolved in methanol and sonicated for $30 \mathrm{~min}$ in an ultrasonic bath. The solution was then centrifuged at $10000 \mathrm{rpm}$ for $10 \mathrm{~min}$ and then later used for high-performance thin-layer chromatography analysis. Each standard was separately weighed and a stock solution was prepared. From each standard stock solution, an equal volume was taken and mixed to prepare a working standard. Thin-layer chromatography densitometric procedure was used to analyze the five major opium alkaloids: morphine, codeine, thebaine, papaverine and narcotine (Gupta, Verma 1996). Toluene-acetone-methanol-ammonia (40:40:6:2) was used as a mobile phase. Silica gel plates $60 \mathrm{~F}_{254}$ (Merck, Darmstadt, Germany) were scanned after derivatization using Dragendorff reagent No. $11 \mathrm{C}$ to detect alkaloid at 540 nm (Wagner et al. 1984).

The pooled data was statistically analyzed for mean value, ANOVA, general combining ability (GCA), specific combining ability (SCA) and reciprocal effect using Statistical Software 4.0 version and the methodology adopted by Yadav et al. (2009a).

Table 2. Results of ANOVA analysis (mean sum squares) for general combining ability (GCA), specific combining ability (SCA) and reciprocal effect for 13 traits in $7 \times 7$ diallel cross of opium poppy. d.f., degrees of freedom, ${ }^{*}, p<0.05 ;{ }^{* *}, p<0.01$

\begin{tabular}{|c|c|c|c|c|c|}
\hline \multirow[t]{2}{*}{ No. } & \multirow[t]{2}{*}{ Characteristic } & \multicolumn{4}{|c|}{ Source of variation } \\
\hline & & GCA (d.f. = 6) & SCA $($ d.f. $=21)$ & Reciprocal $($ d.f. $=21)$ & Error $($ d.f. $=96)$ \\
\hline 1 & Days to $50 \%$ flowering & $64.542^{* *}$ & $31.12^{* *}$ & $19.064^{\star \star}$ & 8.063 \\
\hline 2 & Plant height & $242.55^{\star *}$ & $20.85^{\star *}$ & $45.043^{\star *}$ & 0.181 \\
\hline 3 & Peduncle length & $12.26^{* *}$ & $5.35^{* *}$ & $9.530^{* *}$ & 0.364 \\
\hline 4 & Days to maturity & $303.58^{\star *}$ & $34.07^{\star *}$ & $84.465^{\star *}$ & 3.567 \\
\hline 5 & Number of capsules & $4.53 \times 10^{-2 \star}$ & $9.90 \times 10^{-2 * *}$ & $1.58 \times 10^{-2 \star \star}$ & $6.3 \times 10^{-2}$ \\
\hline 6 & Capsule index & $1.0 \times 10^{-2 * *}$ & $2.0 \times 10^{-2 * *}$ & $2.0 \times 10^{-2 * *}$ & 0.000 \\
\hline 7 & Seed yield & $4.21 \times 10^{-2 \star \star}$ & $4.45 \times 10^{-2 \star}$ & $3.46 \times 10^{-2 \star *}$ & $4.30 \times 10^{-2}$ \\
\hline 8 & Poppy husk yield & $6.49 \times 10^{-2 \star *}$ & $7.45 \times 10^{-2 \star *}$ & $5.32 \times 10^{-2 * *}$ & $2.00 \times 10^{-1}$ \\
\hline 9 & Morphine concentration & $3.30 \times 10^{-4 * *}$ & $1.90 \times 10^{-4 * *}$ & $3.30 \times 10^{-2 * *}$ & $5.20 \times 10^{-4}$ \\
\hline 10 & Codeine concentration & $8.50 \times 10^{-4}$ & $2.20 \times 10^{-6}$ & $5.00 \times 10^{-4}$ & $1.30 \times 10^{-7}$ \\
\hline 11 & Thebaine concentration & $6.70 \times 10^{-6 * *}$ & $6.71 \times 10^{-5 x}$ & $9.90 \times 10^{-6 * *}$ & $2.00 \times 10^{-7}$ \\
\hline 12 & Papaverine concentration & $2.26 \times 10^{-6 * *}$ & $5.03 \times 10^{-6 * *}$ & $4.60 \times 10^{-4 \star \star}$ & $1.32 \times 10^{-6}$ \\
\hline 13 & Narcotine concentration & $1.61 \times 10^{-6 * *}$ & $1.17 \times 10^{-6 * *}$ & $1.88 \times 10^{-5 * *}$ & $1.27 \times 10^{-9}$ \\
\hline
\end{tabular}




\section{Results}

Analysis of variance for combining ability revealed that mean square values were significant for GCA, SCA and reciprocals, thus signifying the role of both additive and non-additive genetic variance, as well as variance due to cytoplasmic differences, for all the thirteen traits studied except for codeine concentration (Table 2).

Early flowering is a desirable characteristic, and therefore a negative value of GCA is desirable for this trait. Three parents showed negative GCA effect where GCA was most pronounced by $\mathrm{P}_{3}$ followed by $\mathrm{P}_{7}$ and $\mathrm{P}_{1}$ (Table 3). $\mathrm{P}_{1}$ had comparatively higher mean (101.93) and negative GCA (gi) (-0.514) values indicating that for this trait $P_{1}$ could be a most desirable parent genotype. Eleven hybrid crosses showed negative SCA effect whereas for earliness the best specific combinations was $\mathrm{P}_{5} \times \mathrm{P}_{6}(-6.03)$ followed by and $\mathrm{P}_{5} \times \mathrm{P}_{7}$ (-4.33). Six crosses, namely $\mathrm{P}_{1} \times \mathrm{P}_{4}, \mathrm{P}_{1} \times \mathrm{P}_{5}$, $\mathrm{P}_{2} \times \mathrm{P}_{5}, \mathrm{P}_{2} \times \mathrm{P}_{6}, \mathrm{P}_{3} \times \mathrm{P}_{5}$ and $\mathrm{P}_{3} \times \mathrm{P}_{6}$, had positive and high SCA effect for days to $50 \%$ flowering, and were considered as undesirable for this trait (Table 4). In context of earliness, desirable negative and significant reciprocal effect were shown by nine crosses (Table 5 ).

Tall plants are always susceptible to lodging and thus plants having medium plant stature were considered for selection and the negative component of combining ability was preferred. Parents $\mathrm{P}_{3}$ and $\mathrm{P}_{7}$ showed desirable negative GCA effect for plant height (Table 3). Seven crosses possessed high negative SCA effect for plant height (Table 4). The desirable reciprocal effect for height, i.e. negative significant values, were shown by several crosses $\left(\mathrm{P}_{3} \times \mathrm{P}_{1}, \mathrm{P}_{3}\right.$ $\times \mathrm{P}_{2}, \mathrm{P}_{5} \times \mathrm{P}_{1}, \mathrm{P}_{5} \times \mathrm{P}_{3}, \mathrm{P}_{6} \times \mathrm{P}_{1}, \mathrm{P}_{6} \times \mathrm{P}_{2}, \mathrm{P}_{6} \times \mathrm{P}_{3}, \mathrm{P}_{6} \times \mathrm{P}_{5}, \mathrm{P}_{7} \times \mathrm{P}_{1}$, $\mathrm{P}_{7} \times \mathrm{P}_{2}, \mathrm{P}_{7} \times \mathrm{P}_{3}, \mathrm{P}_{7} \times \mathrm{P}_{4}, \mathrm{P}_{7} \times \mathrm{P}_{5}$ and $\mathrm{P}_{7} \times \mathrm{P}_{6}$; Table 5).

In context of peduncle length, $\mathrm{P}_{1}$ showed the highest mean (22.43) with positive GCA (gi $=0.43$ ). The negative GCA value for parents $\mathrm{P}_{3}, \mathrm{P}_{4}$ and $\mathrm{P}_{7}$ indicated their poor general combination ability for peduncle length (Table 3 ). Crosses $\mathrm{P}_{1} \times \mathrm{P}_{3}, \mathrm{P}_{1} \times \mathrm{P}_{5}, \mathrm{P}_{2} \times \mathrm{P}_{4}, \mathrm{P}_{3} \times \mathrm{P}_{4}, \mathrm{P}_{4} \times \mathrm{P}_{5}, \mathrm{P}_{4} \times \mathrm{P}_{6}$ and $\mathrm{P}_{6} \times \mathrm{P}_{7}$ showed high SCA effect for peduncle length (Table 4 ). For peduncle length, eight crosses had desirable positive and significant reciprocal effect (Table 5).

Early maturity is a desirable character and therefore negative estimates can be selection criteria. The highest negative GCA effect ( $\mathrm{gi}=-6.394)$ for this trait was exhibited by the parent $\mathrm{P}_{3}$. High negative SCA were shown by $\mathrm{P}_{1} \times \mathrm{P}_{2}$, $\mathrm{P}_{1} \times \mathrm{P}_{3}, \mathrm{P}_{1} \times \mathrm{P}_{6}, \mathrm{P}_{2} \times \mathrm{P}_{3}, \mathrm{P}_{2} \times \mathrm{P}_{4}, \mathrm{P}_{2} \times \mathrm{P}_{5}, \mathrm{P}_{4} \times \mathrm{P}_{5}, \mathrm{P}_{4} \times \mathrm{P}_{6}, \mathrm{P}_{4}$ $\times \mathrm{P}_{7}, \mathrm{P}_{5} \times \mathrm{P}_{7}$ and $\mathrm{P}_{6} \times \mathrm{P}_{7}$, while $\mathrm{P}_{4} \times \mathrm{P}_{2}, \mathrm{P}_{4} \times \mathrm{P}_{3}, \mathrm{P}_{5} \times \mathrm{P}_{2}, \mathrm{P}_{5}$ $\times \mathrm{P}_{3}$ and $\mathrm{P}_{6} \times \mathrm{P}_{1}$ showed high negative reciprocal effect for days to maturity (Tables $4 \& 5$ ). The parent $\mathrm{P}_{6}$ followed by $\mathrm{P}_{3}$ and $\mathrm{P}_{4}$ had the highest mean value (3.00) and positive GCA effect (0.026), for number of capsules/plant. The cross between $\mathrm{P}_{1} \times \mathrm{P}_{3}, \mathrm{P}_{1} \times \mathrm{P}_{4}, \mathrm{P}_{1} \times \mathrm{P}_{5}, \mathrm{P}_{1} \times \mathrm{P}_{6}, \mathrm{P}_{4} \times \mathrm{P}_{6}$ and $\mathrm{P}_{4} \times$ $\mathrm{P}_{7}$ had high SCA for number of capsules per plant while desirable reciprocal effect was found for $\mathrm{P}_{3} \times \mathrm{P}_{2}, \mathrm{P}_{5} \times \mathrm{P}_{1}, \mathrm{P}_{5}$ $\times \mathrm{P}_{3}$, and $\mathrm{P}_{6} \times \mathrm{P}_{4}$. In respect to capsule index, the parent $\mathrm{P} 4$ recorded ahigh mean value (0.971) and higher GCA effect (0.009). High significant SCA were seen in the crosses $P_{1} \times$ $\mathrm{P}_{3}, \mathrm{P}_{1} \times \mathrm{P}_{5}, \mathrm{P}_{1} \times \mathrm{P}_{6}, \mathrm{P}_{2} \times \mathrm{P}_{3}, \mathrm{P}_{2} \times \mathrm{P}_{4}, \mathrm{P}_{2} \times \mathrm{P}_{5}, \mathrm{P}_{2} \times \mathrm{P}_{7}, \mathrm{P}_{3} \times \mathrm{P}_{6}, \mathrm{P}_{4}$ $\times \mathrm{P}_{5}, \mathrm{P}_{4} \times \mathrm{P}_{7}, \mathrm{P}_{5} \times \mathrm{P}_{6}, \mathrm{P}_{5} \times \mathrm{P}_{7}$ and $\mathrm{P}_{6} \times \mathrm{P}_{7}$. For this trait high reciprocal effect was expressed by hybrids $\mathrm{P}_{2} \times \mathrm{P}_{1}$ and $\mathrm{P}_{5} \times$ $\mathrm{P}_{1}$ (Tables 3, 4, 5).

In perspective of the economically important trait like seed yield per plant, $\mathrm{P}_{1}$ was the most desirable parent as it had notably a high mean value along with the highest desirable positive GCA effect (0.20). For seed yield, significant high SCA was recorded for all crosses except for $\mathrm{P}_{1} \times \mathrm{P}_{2}, \mathrm{P}_{1} \times \mathrm{P}_{4}$ and $\mathrm{P}_{1} \times \mathrm{P}_{7}$, while high reciprocal effect was seen for $\mathrm{P}_{2} \times \mathrm{P}_{1}, \mathrm{P}_{3} \times \mathrm{P}_{1}, \mathrm{P}_{4} \times \mathrm{P}_{1}, \mathrm{P}_{5} \times \mathrm{P}_{1}, \mathrm{P}_{5} \times \mathrm{P}_{2}, \mathrm{P}_{5} \times \mathrm{P}_{3}, \mathrm{P}_{6}$ $\times \mathrm{P}_{1}, \mathrm{P}_{6} \times \mathrm{P}_{4}, \mathrm{P}_{6} \times \mathrm{P}_{5}, \mathrm{P}_{7} \times \mathrm{P}_{1}, \mathrm{P}_{7} \times \mathrm{P}_{4}$ and $\mathrm{P}_{7} \times \mathrm{P}_{6}$. For capsule husk yield, the parent $\mathrm{P} 1$ had a notable mean value (6.22) and the highest positive GCA effect (0.32). For capsule husk yield, 16 and 9 crosses showed significant positive GCA and reciprocal effect, respectively (Tables $4 \& 5$ ).

For the pharmaceutically important alkaloid concentration like that of morphine, parents $\mathrm{P}_{5}$ and $\mathrm{P}_{6}$ exhibited a high mean value as well as high GCA effect $(9.6 \times$ $\left.10^{-4}, 6.12 \times 10^{-4}\right)$ indicating they usefulness for development of high morphine containing varieties. Parents $\mathrm{P}_{1}, \mathrm{P}_{2}$ and $\mathrm{P}_{4}$ showed negative GCA effect for morphine concentration, signifying their potential use in development of morphineless varieties. For morphine concentration, high SCA was recorded for crosses $\mathrm{P}_{1} \times \mathrm{P}_{6}, \mathrm{P}_{2} \times \mathrm{P}_{5}, \mathrm{P}_{2} \times \mathrm{P}_{6}, \mathrm{P}_{3} \times \mathrm{P}_{4}, \mathrm{P}_{3} \times \mathrm{P}_{5}$, $\mathrm{P}_{3} \times \mathrm{P}_{6}, \mathrm{P}_{3} \times \mathrm{P}_{7}$ and $\mathrm{P}_{5} \times \mathrm{P}_{7}$, while high reciprocal effect was noted for $\mathrm{P}_{2} \times \mathrm{P}_{1}, \mathrm{P}_{4} \times \mathrm{P}_{1}, \mathrm{P}_{2} \times \mathrm{P}_{3}, \mathrm{P}_{5} \times \mathrm{P}_{1}, \mathrm{P}_{5} \times \mathrm{P}_{4}, \mathrm{P}_{6} \times \mathrm{P}_{5}$ and $\mathrm{P}_{7} \times \mathrm{P}_{5}$. For codeine concentration, $\mathrm{P} 6$ had the highest mean value $\left(1.0 \times 10^{-1}\right)$ and high GCA effect $\left(1.49 \times 10^{-4}\right)$ while high SCA was evident for $\mathrm{P}_{1} \times \mathrm{P}_{5}, \mathrm{P}_{1} \times \mathrm{P}_{6}, \mathrm{P}_{2} \times \mathrm{P}_{4}, \mathrm{P}_{2} \times$ $\mathrm{P}_{7}, \mathrm{P}_{3} \times \mathrm{P}_{4}, \mathrm{P}_{3} \times \mathrm{P}_{7}$, and $\mathrm{P}_{4} \times \mathrm{P}_{7}$. Several crosses $\left(\mathrm{P}_{3} \times \mathrm{P}_{2}, \mathrm{P}_{4} \times\right.$ $\mathrm{P}_{3}, \mathrm{P}_{5} \times \mathrm{P}_{1}, \mathrm{P}_{5} \times \mathrm{P}_{4}, \mathrm{P}_{6} \times \mathrm{P}_{1}, \mathrm{P}_{6} \times \mathrm{P}_{4}, \mathrm{P}_{7} \times \mathrm{P}_{4}, \mathrm{P}_{7} \times \mathrm{P}_{5}$ ) expressed significant reciprocal effect for codeine concentration. For thebaine concentration, the parent genotype $\mathrm{P} 6$ possessed the highest mean value $\left(4.3 \times 10^{-3}\right)$ as well as positive GCA effect $\left(3.6 \times 10^{-4}\right)$ and promising hybrids were $\mathrm{P}_{1} \times \mathrm{P}_{4}, \mathrm{P}_{1} \times$ $\mathrm{P}_{5}, \mathrm{P}_{1} \times \mathrm{P}_{6}, \mathrm{P}_{2} \times \mathrm{P}_{5}, \mathrm{P}_{2} \times \mathrm{P}_{7}, \mathrm{P}_{3} \times \mathrm{P}_{4}, \mathrm{P}_{3} \times \mathrm{P}_{7}, \mathrm{P}_{4} \times \mathrm{P}_{5}$ and $\mathrm{P}_{4}$ $\times \mathrm{P}_{7}$. Besides this, the hybrid lines $\mathrm{P}_{2} \times \mathrm{P}_{1}, \mathrm{P}_{3} \times \mathrm{P} 1, \mathrm{P}_{3} \times \mathrm{P}_{2}$, $\mathrm{P}_{4} \times \mathrm{P}_{2}, \mathrm{P}_{4} \times \mathrm{P}_{3}, \mathrm{P}_{5} \times \mathrm{P}_{1}, \mathrm{P}_{5} \times \mathrm{P}_{4}, \mathrm{P}_{6} \times \mathrm{P}_{1}, \mathrm{P}_{6} \times \mathrm{P}_{4}, \mathrm{P}_{6} \times \mathrm{P}_{5}, \mathrm{P}_{7}$ $\times \mathrm{P}_{2}, \mathrm{P}_{7} \times \mathrm{P}_{4}$ and $\mathrm{P}_{7} \times \mathrm{P}_{5}$ possesed high reciprocal effect. In context of papaverine the parent genotype $\mathrm{P}_{6}$ had a high mean value $\left(2.3 \times 10^{-3}\right)$ and positive GCA $\left(3.6 \times 10^{-3}\right)$. For papaverine concentration, the crosses $\mathrm{P}_{1} \times \mathrm{P}_{5}, \mathrm{P}_{2} \times \mathrm{P}_{4}, \mathrm{P}_{2} \times$ $\mathrm{P}_{5}, \mathrm{P}_{2} \times \mathrm{P}_{6}, \mathrm{P}_{3} \times \mathrm{P}_{5}, \mathrm{P}_{3} \times \mathrm{P}_{6}, \mathrm{P}_{3} \times \mathrm{P}_{7}$ and $\mathrm{P}_{4} \times \mathrm{P}_{7}$ showed high SCA, whereas out of 21 crosses 12 had positive reciprocal effect and the remaining had negative effect. For narcotine, the parent genotype $\mathrm{P}_{6}$ did not have the highest mean value but showed positive and desirable GCA $\left(2.0 \times 10^{-2}\right)$. Hence it was good combiner with other parents. The crosses $\mathrm{P}_{1} \times$ $\mathrm{P}_{6}, \mathrm{P}_{1} \times \mathrm{P}_{7}, \mathrm{P}_{2} \times \mathrm{P}_{5}, \mathrm{P}_{2} \times \mathrm{P}_{6}, \mathrm{P}_{2} \times \mathrm{P}_{7}, \mathrm{P}_{3} \times \mathrm{P}_{5}, \mathrm{P}_{3} \times \mathrm{P}_{7}, \mathrm{P}_{4} \times \mathrm{P}_{5}$ and $\mathrm{P}_{5} \times \mathrm{P}_{7}$ exhibited high SCA for narcotine concentration, while crosses with significant reciprocal effect were $\mathrm{P}_{3} \times \mathrm{P}_{2}$, $\mathrm{P}_{6} \times \mathrm{P}_{4}, \mathrm{P}_{7} \times \mathrm{P}_{3}$ and $\mathrm{P}_{7} \times \mathrm{P}_{5}$ (Tables $\left.3,4,5\right)$. 


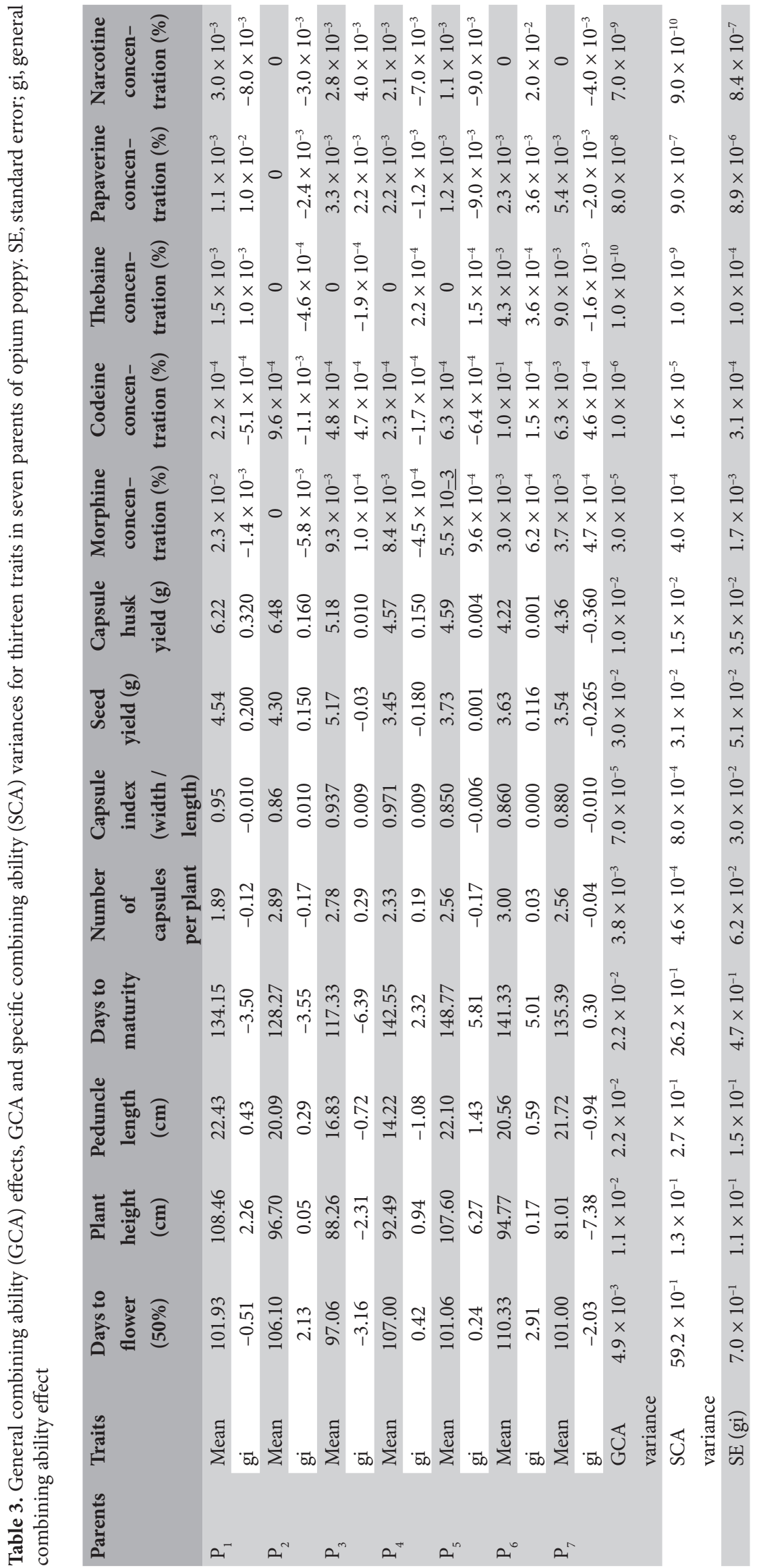




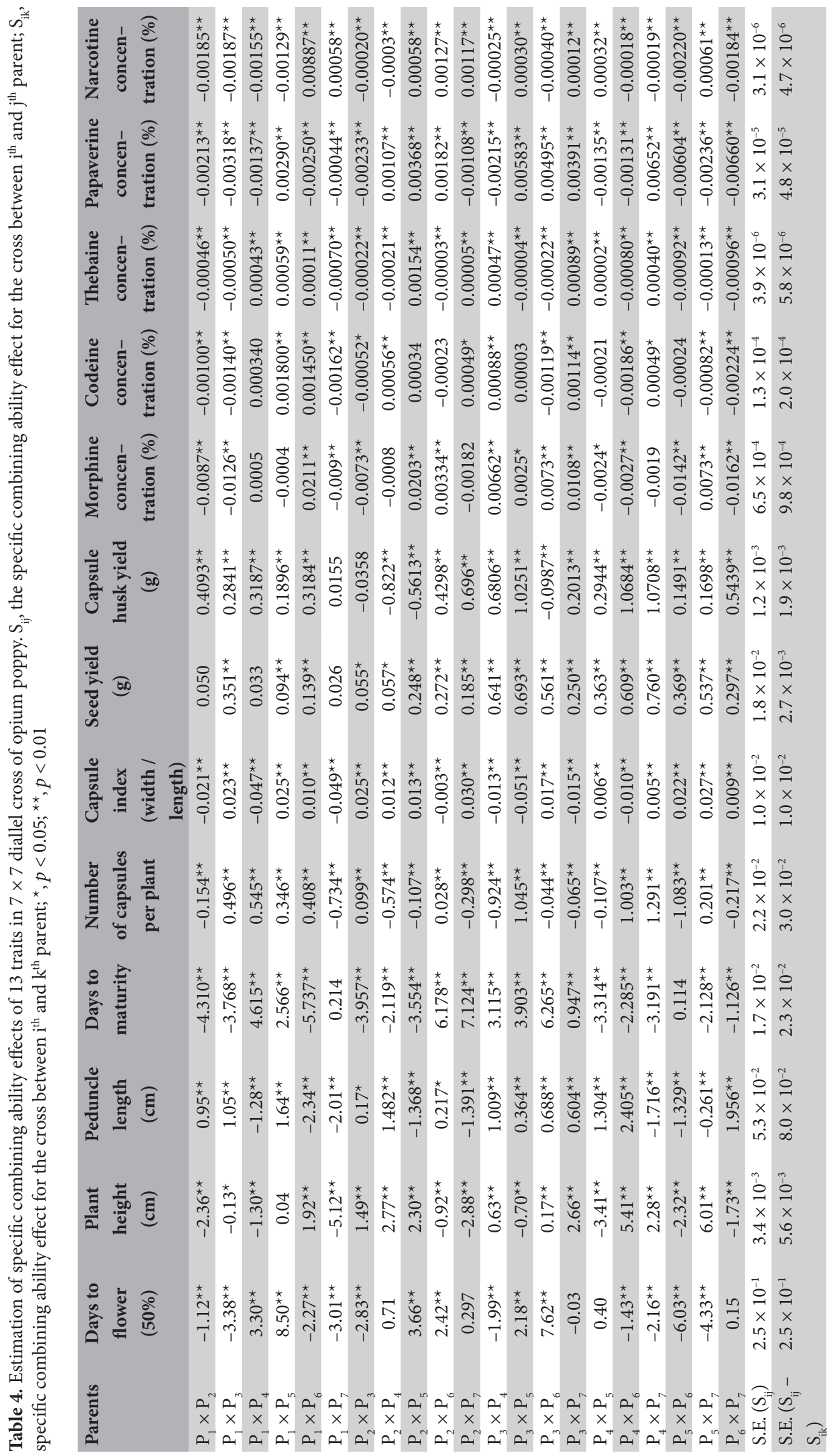




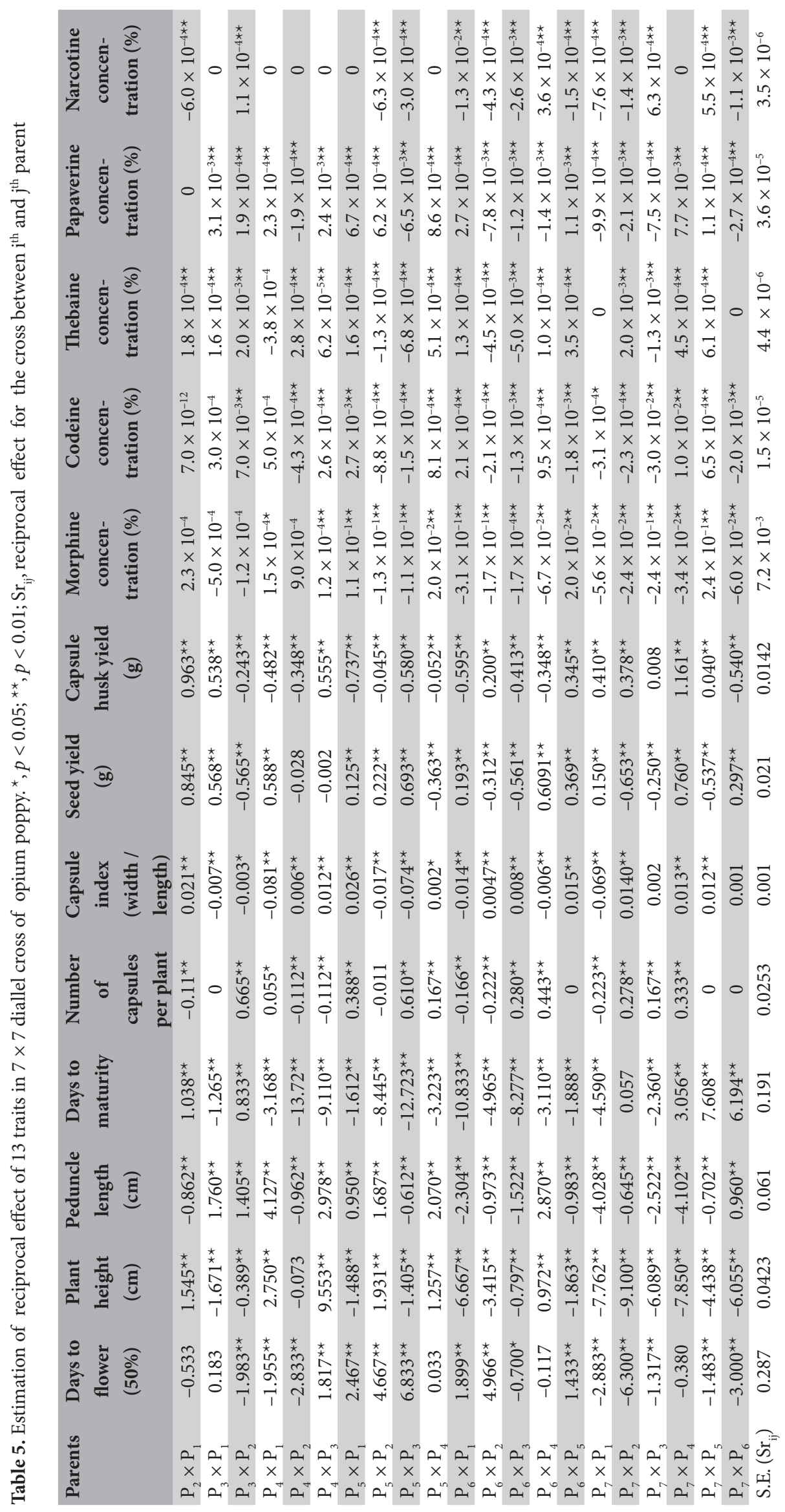




\section{Discussion}

It is evident that the majority of the studied traits exhibited significant general combining ability, specific combining ability and reciprocal effect mean squares, and manifested importance of additive, non-additive gene action as well as maternal effects. Earlier studies also reported that in opium poppy both additive and non-additive genetic variation played important roles in the inheritance of poppy latex and straw alkaloid content (Singh et al. 2011; Lal et. al 2014; Shukla et al 2019). Both additive and nonadditive genetic components of variance were reported to govern the expression of opium yield and physiological characters (Kandalkar et al. (1992). Early flowering is a desirable character in opium poppy, as it provides sufficient time for seed filling in capsules, which could help in achieving increased seed yield. Similarly, medium plant height prevents lodging of crops, while characters like early maturity helps crops to escape pest losses and unwanted damage $>$ Thus, these characters should be taken into account for negative combing ability. Taller plants are susceptible to lodging, and therefore, medium or shortstatured plants are desirable, and for that negative GCA and SCA values are preferred (Singh, Khanna 1993; Singh et al. 2004; Ali et al. 2015). Hence, negative combining ability effects for early days to flowering and early maturity are required to get higher yields. For days to flowering, $\mathrm{P}_{1}$, $\mathrm{P}_{3}$ and $\mathrm{P}_{7}$ showed negative GCA and their hybrids showed high negative SCA, supporting that these three parents are good combiners. Similar findings for GCA were reported for days to flowering, capsule number and latex yield (Dubey et al. 2007). For plant height, $\mathrm{P}_{3}$, and $\mathrm{P}_{7}$ had negative GCA and their hybrids also showed significant and high negative SCA and significant reciprocal effect. $\mathrm{P}_{1}, \mathrm{P}_{2}$ and $\mathrm{P}_{3}$ showed negative significant GCA for days to maturity and most of the hybrids involving these parents had significant SCA and reciprocal effect. Higher seed yield is the priority of breeding programmes, and hence improvement in yield and its components are prerequisites. Desirable GCA, SCA and reciprocal effects were recorded in selected parental genotypes and their hybrids, respectively. Therefore, positive combining ability effects were considered desirable for seed yield. $\mathrm{P}_{1}, \mathrm{P}_{2}, \mathrm{P}_{5}$ and $\mathrm{P}_{6}$ showed positive GCA while $\mathrm{P}_{3}, \mathrm{P}_{4}$ and $\mathrm{P}_{7}$ had negative GCA, but SCA was significant for crosses low in GCA, showing that the high $\times$ low GCA parents were involved in best specific combinations. Our results were in accordance with the findings of earlier studies with opium poppy (Sharma et al. 1988; Yadav et al. 2014b; Kumar et al. 2014; Lal et al. 2014).

In relation to medicinally important alkaloids in the final tally, positive GCA was evident for parents $\mathrm{P}_{3}, \mathrm{P}_{5}, \mathrm{P}_{6} \& \mathrm{P}_{7}$ (morphine); $\mathrm{P}_{3}, \mathrm{P}_{6} \& \mathrm{P}_{7}$ (codeine); $\mathrm{P}_{1}, \mathrm{P}_{4}, \mathrm{P}_{5} \& \mathrm{P}_{6}$ (thebaine); parents, $\mathrm{P}_{1}, \mathrm{P}_{3} \& \mathrm{P}_{6}$ (papaverine) and $\mathrm{P}_{6}$ (narcotine). Among all parents, genotype $\mathrm{P}_{6}$ had the most desirable level of GCA, SCA and reciprocals for most of considered agronomic and biochemical traits, an consequently it is most important isolate in this study that could be utilized in a variety of ways.

In conclusion, diallel analysis is a useful tool in identification of parents for hybrid combination. The majority of the traits exhibited significant GCA and SCA mean squares, and manifested importance of additive, nonadditive gene action and maternal effects. The identified genotypes $\mathrm{P}_{3}, \mathrm{P}_{4}$ and $\mathrm{P}_{6}$ are important in relation to seed yield, development of morphine-less cultivars and quantitative alkaloid yield in capsule husk, respectively, and can be utilized for genetic improvement programmes to obtain desired traits of P. somniferum.

\section{Acknowledgements}

Authors thanks to the Director, CSIR-CIMAP, Lucknow for the encouragement and facilities provided during the investigation. Author Rashmi Lahiri thanks CSIR, New Delhi, for providing Senior Research Fellowship.

\section{References}

Ali N., Khan N.U., Ali S., Gul S., Saeed M., Naveed K. 2015. Combining ability studies for quantitative traits in Brassica juncea. J. Anim. Plant Sci. 25: 494-501.

Dubey R.B., Jain S.K., Maloo S.R. 2007. Combining ability and heterosis for latex yield, seed yield and other agronomic traits in opium poppy (Papaver somniferum L.). Indian J. Genet. Plant Breed. 67: 392-395.

Frick S., Kramell R., Schmidt J., Fist A.J., Kutchan T.M. 2005. Comparative qualitative and quantitative determination of alkaloids in narcotic and condiment Papaver somniferum cultivars. J. Nat. Prod. 68: 666-673.

Griffing B. 1956a. Concept of general and specific combining ability in relation to diallel crossing system. Austr. J. Biol. Sci. 9:463-493.

Griffing B.1956b. A generalised treatment of the use of diallel crosses in quantitative inheritance. Heredity 10: 31-50.

Gümüşçü A., Arslan N. 2009. Researches on general and specific combining ability of yield and some traits of the hybrids of selected poppy (Papaver somniferum L.) lines. Acta Hortic. 826: 105-110.

Gupta M.M., Verma R.K. 1996. Combined thin layer chromatography-densitometry method for the quantitative estimation of major alkaloid in poppy straw samples. Indian J. Pharm. Sci. 58: 161-162.

Hofman P.J., Menary R.C. 1979. Variations in morphine, codeine and thebaine in the capsules of Papaver somniferum L. during maturation. Austr. J. Agric. Res. 31: 313-326.

Kandalkar V.S., Patidar H., Nigam K.B. 1992. Combining ability analysis for harvest index, seed yield and important component characters in opium poppy (Papaver somniferum L.). Indian J. Genet. Plant Breed. 52: 275-279.

Kumar B., Patra N.K. 2011. Combining ability for inheritance of economic traits in opium poppy (Papaver somniferum L.). Bangladesh J. Plant Breed. Genet. 24: 1-8.

Kumar B., Singh H.P., Patra N.K. 2010. Inheritance of quantitative traits in opium poppy (Papaver somniferum L.). Biometry Crop Sci. 5: 11-18.

Kumar B., Singh V.R., Ram G., Singh H.P. 2014. Genetic 
combiningability estimates for inheritance of economic traits in opium poppy (Papaver somniferum L.) Acta Hortic. 1036: 43-50.

Lal R.K., Gupta V., Gupta P., Sarkar S., Singh S. 2014. Genetics and inheritance pattern of heterosis in impact of genetic divergence in opium poppy (Papaver somniferum L.). J. Herbs Spices Med. Plants 20: 70-82.

Marciano M., Panicker S.X., Liddil G.D., Lindgren D., Sweder K.S. 2018. Development of a method to extract opium poppy (Papaver somniferum L.) DNA from heroin. Sci. Rep. 8: 2590.

Nergiz C., Otles S. 1994. The proximate composition and some minor constituents of poppy seeds. J. Sci. Food Agric. 66: 117120.

Pathak S., Lakhwani D., Gupta P., Mishra B.K., Shukla S., Asif M.H., Trivedi P.K. 2013. Comparative transcriptome analysis using high papaverine mutant of Papaver somniferum reveals pathway and uncharacterized steps of papaverine biosynthesis. PLoS ONE 8: e65622.

Rastogi A., Mishra B.K., Siddiqui A., Srivastava M., Shukla S. 2013. Biplot analysis based on diallel for exploitation of hybrid vigour in opium poppy (Papaver somniferum L.). J. Agric. Sci. Technol. 15: 151-162.

Sacks F.M., Campos H. 2006. Polysaturated fatty acids, inflammation and cardiovascular diseases: Time to widen our view of the mechanism. J. Clin. Endocrinol. Metab. 91: 398-400.

Sharma JR., Lal R.K., Mishra H.O., Sharma S. 1988. Heterosis and gene action for important traits in opium poppy (Papaver somniferum L.). Indian J. Genet. Plant Breed. 48: 261-266.

Shukla S., Lal R.K., Singh V.R., Shanker K. 2019. Estimation of components of genetic variation and graphical analysis in opium poppy (Papaver somniferum L.). Adv. Crop Sci. Technol. 7: $1-8$.

Singh R., Pandey R.M. 2011. Combining ability and heterosis in opium poppy (Papaver somniferum L.). Curr. Adv. Agric. Sci. 3: $130-134$.

Singh S.P., Shukla S., Yadav H.K. 2004. Genetic studies and their implication to breed desired plant type in opium poppy, Papaver somniferum L. Genetika 36: 69-81.

Singh S.P., Khanna, K.R. 1993. Path coefficient analysis for opium and seed yield in the opium poppy (Papaver somniferum L.). Genetika 25: 119-128.

Vos E., Cunnne S.C. 2003. $\alpha$-Linolenic acid, linoleic acid, coronary heart diseases and overall mortality. Am. J. Clin. Nutr. 72: 521-522.

Wagner H., Bladt S., Zgainski E.M. 1984. Plant drug analysis. In: A Thin Layer Chromatography Atlas. Springer-Verlag, Berlin, pp. 300-301.

Yadav H.K. Shukla S., Singh S.P. 2009a. Genetic combining ability estimates in the F1 and F2 generations for yield, its component traits and alkaloid content in opium poppy (Papaver somniferum L.). Euphytica 168: 23-32.

Yadav H.K., Maurya K.N., Shukla S., Singh S.P. 2009b. Combining ability of opium poppy genotypes over $\mathrm{F} 1$ and $\mathrm{F} 2$ generations of $8 \times 8$ diallel cross. Crop Breed. Appl. Biotechnol. 9: 353-360.

Yan W., Hunt L.A. 2002. Biplot analysis of diallel data. Crop Sci. 42: $21-30$

Yazici L., Yilmaz G. 2020. Hybrid vigor for alkaloid contents in opium poppy (Papaver somniferum L.). Indian J. Agric. Res. DOI 10.18805/IJARe.A-496. 